[Agr. Biol. Cnem., Vol. 31, No. 2, p. 150 159, 1967]

\title{
Purification of Yeast Proteinases
}

\section{Part I. Fractionation and Some Properties of the Proteinases}

\author{
By Tadao Hata, Rikimaru HAyashi and Etsushiro DoI
}

The Research Institute for Food Science, Kyoto University, Kyoto

Received August 16, 1966

\begin{abstract}
Three types of proteinases contained in baker's yeast were fractionated and partially purified by chromatography on TEAE-cellulose and on DEAE-Sephadex. These enzymes were designated as proteinase $\mathrm{A}, \mathrm{B}$ and $\mathrm{C}$, and some properties of proteinase $\mathrm{A}$ and $\mathrm{B}$ were described.

A was similar to pepsin and "acid-proteinase" produced by various fungi, but did not hydrolyze carbobenzoxy-L-glutamyl-L-tyrosine. B had milk-clotting activity and proteolytic activity toward casein, and also esterolytic activity toward $\mathrm{N}$-acetyl-L-tyrosine ethylester and $\alpha$-N-benzoyl-L-arginine ethylester. This enzyme was inhibited by $p$-mercuribenzoate and diisopropylphosphorofluoridate.
\end{abstract}

\section{INTRODUCTION}

It has long been known that some proteinases and peptidases are contained in yeast cells and can be liberated after the cells are broken by autolysis. ${ }^{\prime \prime}$

Yeast exopeptidases were studied in detail and the characteristics of each enzyme have been clarified by Grassmann et al., ${ }^{2 \sim 4)}$ Johnson $^{51}$ and Felix et $a^{61}$ On the other hand, yeast proteinases have not been made clear and inconsistent results have been obtained. These enzymes were described first by Dernby ${ }^{n}$

* This investigation was supported in part by a grant-in-aid for the scientific research from the Ministry of Education. This report was presented at the Annual Meeting of the Agricultural Chemical Society of Japan, Sapporo, July, 1964.

i) G. Harris, "The Chemistry and Biology of Yeasts" edited by A. H. Cook, Academic Press, 1958, p. 437 .

2) R. Willstätter and W. Grassmann, Z. physiol. Chem., 153, 250 (1926).

3) W. Grassmann and W. Haag, ibid., 167, 188 (1927).

4) W. Grassmann and H. Dyckerhoff, ibid., 179, 41 (1928).

5) M.J. Johnson, J. Biol. Chem., 137, 575 (1940).

6) F. Felix and J. Labouesse-Mercouroff, Biochim. Biophys. Acta, 21, 303 (1956).

7) K. G. Dernby, Biochem. Z., 81, 107 (1917). as "Hefetryptase" and "Hefepepsin", with optimum $\mathrm{pH}$ at 7.0 and 4.5 , respectively. According to Grassmann et al., ${ }^{2-4)}$ yeast contained only one proteinase similar to papain, which was most active to many proteins at $\mathrm{pH} 5.0$. Thereafter, Hecht and Civin ${ }^{8)}$ described that pepsin-like proteinase acting at $\mathrm{pH} 1.8$ was present in the yeast autolysate.

Recently, Lenney' ${ }^{91}$ proved that the yeast proteinase consisted of two enzymes, measuring the activity by the method of Kunitz. ${ }^{11}$ $\mathrm{He}$ reported that the two proteinases, $\mathrm{A}$ and $B$, were liberated by the autolysis of four different strains of Saccharomyces cerevisiae with chloroform. A exhibited an optimal $\mathrm{pH}$ of 3.7 for acid-denatured hemoglobin and was extremely labile in urea solution. On the other hand, $\mathrm{B}$ exhibited an optimal $\mathrm{pH}$ of 6.2 on urea-denatured proteins and was stable in urea solution and inhibited by sulfhydryl reagents. But purification and further characterization of these enzymes have not yet been performed by any authors.

8) M. Hecht and H. Civin, J. Biol. Chem., 116, 477 (1936).

9) J. F. Lenney, ibid., 221, 919 (1956). 
In the present series of studies, ${ }^{101}$ proteinases of yeast have been fractionated by chromatography on TEAE-cellulose and DEAE-Sephadex columns, and separated into three enzymes which were designated as yeast proteinase $\mathrm{A}, \mathrm{B}$ and $\mathrm{C}$.

\section{MATERIALS AND METHODS}

Materials. Compressed baker's yeast was obtained from Oriental Yeast Company. Hammarsten's case in was purchased from E. Merck AG., Darmstadt. Hemoglobin was a product from Difco Laboratories. $\mathrm{N}$-Acetyl-L-tyrosine ethylester (ATEE), $\alpha$-N-benzoylL-arginine ethylester (BAEE) and other synthetic substrates were purchased from Mann Research Laboratories, Inc. and used without any further purification. Diisopropylphosphorofluoridate (DFP) was purchased from Sigma Chemical Company. Soy bean trypsin inhibitor was obtained from Nutritional Biochemical Corporation. $p$-Mercuribenzoate (PCMB) was used after recrystalization.

Measurement of enzyme activity. Proteolytic activity was measured by the method of Kunitzin, and Hagihara ef al.12) with the modification for micro scale. The incubation mixture contained $2 \mathrm{ml}$ of protein solution and $0.4 \mathrm{ml}$ of enzyme solution. After incubating at $25^{\circ} \mathrm{C}$ for thirty minutes, $2 \mathrm{ml}$ of $0.44 \mathrm{M}$ trichloroacetic acid was added and the absorbancy at $280 \mathrm{~m} \mu$ of trichloroacetic acid-soluble products was measured with Shimadzu Model QR-50 spectrophotometer. The proteolytic activity in each purification step was measured by using $0.5 \%$ casein solution as the substrate, at $\mathrm{pH} 6.0$, because the optimal conditions of each enzyme were not known before the individual enzyme has been purified. So, after each enzyme was purified, the activity was assayed at optimal conditions of the individual enzyme by using $1 \%$ casein or $1 \%$ acid-denatured hemoglobin solution $(\mathrm{HCl}-\mathrm{Hb})^{13)}$ as the substrate. The esterolytic activity was determined by pH-stat method using Radiometer Model SBR2/SBU1/TTT1 titration equipment with $0.01 \mathrm{~N} \mathrm{NaOH}$ as the titrant. Reaction mixture contained enzyme, $10 \mathrm{mM}$ ATEE or BAEE, and $100 \mathrm{~mm}$

10) E. Doi, R. Hayashi and T. Hata, This Journal, 31, 160 (1967).

11) M. Kunitz, J. Gen. Physiol., 30, 291 (1947).

12) B. Hagihara, H. Matsubara, M. Nakai and K. Okunuki, J. Biochem. (Tokyo), 45, 185 (1958).

13) M. Schlamowitz and L. U. Peterson, J. Biol. Chem., 234, 3137 (1959).
$\mathrm{KCl}$ in $2.5 \mathrm{ml}$ of the total solution. It was held at $25^{\circ} \mathrm{C}$ with circulating water and kept under nitrogen gas stream.

Determination of protein concentration and nitrogen content. Protein concentration was determined by the method of Lowry et al.14) using bovine serum albumin as the standard. Nitrogen content was measured by micro-Kjeldahl method.

\section{RESULTS}

1. Fractionation and Purification of the Proteinases.

a) Autolysis and preparation of the crude extract. Autolysis and the extraction of yeast proteinases were carried out as described by Lenney $^{9 \prime}$ with a slight modification. Twenty pounds of compressed baker's yeast were plasmolyzed with $4,000 \mathrm{ml}$ of chloroform. After thirty to sixty minutes at room temperature, $4,000 \mathrm{ml}$ of distilled water was added and the $\mathrm{pH}$ was adjusted to 7.0 with $1 \mathrm{~N}$ $\mathrm{NaOH}$. After the autolysis had been carried out at about $25^{\circ} \mathrm{C}$ overnight, the suspension was centrifuged at 3,000 r.p.m. for twenty minutes and the supernatant solution was adjusted to $\mathrm{pH} 5.0$, then allowed to stand under toluene at about $25^{\circ} \mathrm{C}$ overnight. After centrifugation, the supernatant solution (7.4 1 , $15.66 \mathrm{mg}$ of protein per $\mathrm{ml}$ ) was obtained as the crude extract.

b) Fractionation with ammonium sulfate. Since most proteins and proteinases in the crude extract did not precipitate with less than $75 \%$ saturation of ammonium sulfate, the crude extract was fractionated by adding ammonium sulfate to $90 \%$ saturation at $\mathrm{pH}$ 5.0 , and was centrifuged at 15,000 r.p.m. for thirty minutes with batch rotor of Spinco Model L ultracentrifuge. The precipitate was dissolved in small amounts of water and dialyzed against $0.01 \mathrm{M}$. sodium phosphate buffer $(\mathrm{pH} 7.0)$ containing $0.1 \mathrm{M}$ sodium chloride at $5^{\circ} \mathrm{C}$ overnight. Dialyzed solution $(1,200 \mathrm{ml}$, $8.25 \mathrm{mg}$ of protein per $\mathrm{ml}$ ), after centrifuga-

14) O. H. Lowry, N. J. Rosenbrough, A. L. Forr and R. J. Randall, J. Biol. Chem., 193, 265 (1951). 
tion to remove small amounts of precipitates, was passed through TEAE-cellulose column $(6.5 \times 24 \mathrm{~cm}$, volume $800 \mathrm{ml})$ equilibrated with the same buffer as dialyzing solution in order to separate large amounts of nucleic acids and their related compounds. Then, the protein was eluted with $0.01 \mathrm{~m}$ sodium phosphate buffer ( $\mathrm{pH} 7.0$ ) containing $0.4 \mathrm{M}$ sodium chloride, $500 \mathrm{ml}$ of the first eluate was discarded and next $1,750 \mathrm{ml}$ of the eluate $(5.5 \mathrm{mg}$ of protein per $\mathrm{ml}$ ) was collected. This eluate was concentrated with carbowax in a cold room and then dialyzed against $0.01 \mathrm{~m}$ sodium phosphate buffer ( $\mathrm{pH} 7.0$ ) containing $0.1 \mathrm{~m}$ sodium chloride at $5^{\circ} \mathrm{C}$ for twenty four hours.

c) Preliminary experiments to detect various proteinases. Ten $\mathrm{ml}$ of dialyzed solution was applied on TEAE-cellulose column $(1 \times 5 \mathrm{~cm})$ equilibrated with $0.01 \mathrm{M}$ sodium phosphate buffer ( $\mathrm{pH} 7.0)$ and eluted by increasing stepwise the concentration of sodium chloride from 0 to $0.4 \mathrm{M}$ in sodium phosphate buffer $(\mathrm{pH} 7.0)$. Casein digestion at $\mathrm{pH} 6.0$ with and without $10^{-3} \mathrm{M}$ mercuric chloride was tested for each fraction. The result is shown in Fig. 1.

As the results, two fractions exhibiting proteinase activity, one of which was not inhibited and the other was inhibited by mercuric

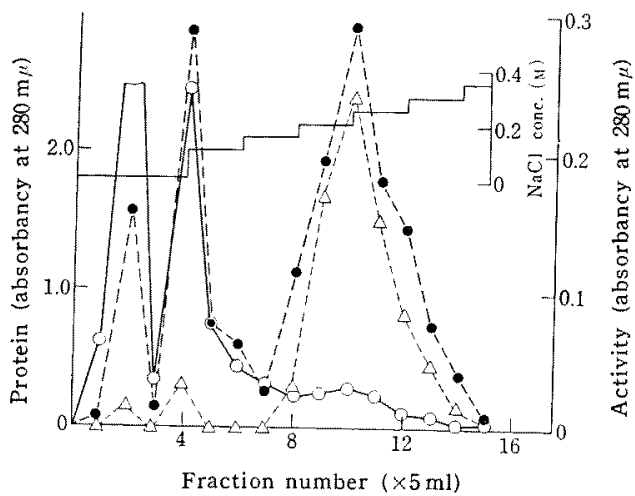

FIG. 1. Preliminary Chromatography on TEAECellulose Column $(1 \times 5 \mathrm{~cm})$.

$(\mathrm{O}-\mathrm{O})$ Protein (---) Activity $\left(-\mathrm{HgCl}_{2}\right)$ $(\triangle-\cdots \triangle)$ Activity $\left(+\mathrm{HgCl}_{2}\right)(-, \mathrm{NaCl}$ conc. chloride, were fractionated. Thus, at least two proteinases were found in this dialyzing solution.

d) Chromatography on TEAE-cellulose. Dialyzed solution $(125 \mathrm{ml}, 52.5 \mathrm{mg}$ of protein per ml) was applied on TEAE-cellulose column $(3.8 \times 32 \mathrm{~cm})$ equilibrated with the same buffer as the dialyzing solution. The elution was performed by increasing logarithmically the concentration of sodium chloride from $0.1 \mathrm{M}$ to $0.4 \mathrm{~m}$ in $0.01 \mathrm{~m}$ phosphate buffer ( $\mathrm{pH} \mathrm{7.0)}$. A typical elution pattern is shown in Fig. 2.

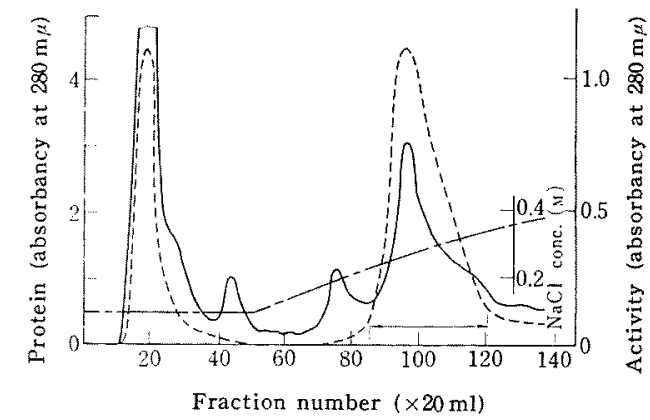

FIG. 2. The First Chromatography on TEAE-Cellulose Column $(3.8 \times 32 \mathrm{~cm})$.

(, Protein (-..) Activity (-..,) NaCl conc.

As the results, two fractions exhibiting strong proteolytic activity were obtained. One of them, which was eluted in the "break-through" fraction, showed strong activity on casein digestion at $\mathrm{pH} 6.0$ and also milk-clotting activity. However, these activities were lost mostly in standing at $5^{\circ} \mathrm{C}$ or even in freezing at $-17^{\circ} \mathrm{C}$ overnight. As described later, only proteinase $B$ showed these activities, but further purification was impossible owing to the instability of the enzyme. The other fraction exhibiting proteolytic activity was pooled as indicated with an arrow in Fig. 2 and further purification was performed. The collected solution ( $720 \mathrm{ml}, 0.82 \mathrm{mg}$ of protein per ml) was precipitated by adding ammonium sulfate to $90 \%$ saturation at $\mathrm{pH}$ 5.0. After the precipitate was dissolved in a small amount of water, the solution was dialyzed in the same 
way as described before the chromatography. The dialyzed solution $(55 \mathrm{ml}, 10.2 \mathrm{mg}$ of protein per $\mathrm{ml}$ ) was applied to the TEAE-cellulose column $(2.1 \times 25.8 \mathrm{~cm})$ and rechromatographed by the same method. As shown in Fig. 3, a single component of protein was obtained on this chromatography. The fraction $(380 \mathrm{ml}, 1.1 \mathrm{mg}$ of protein per $\mathrm{ml}$ ), pooled

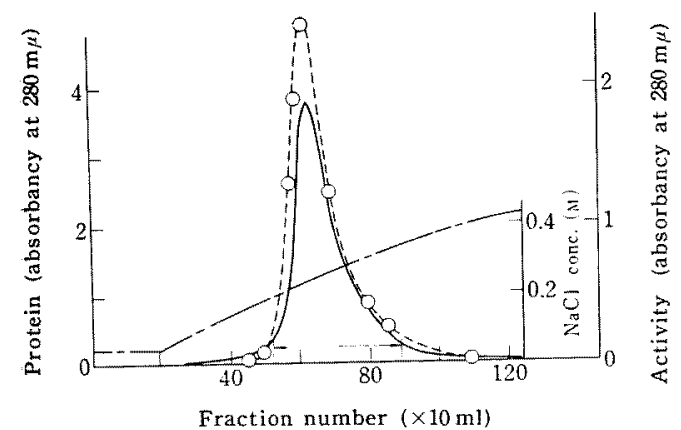

FIG. 3. The Second Chromatography on TEAECellulose Column $(2.1 \times 26 \mathrm{~cm})$.

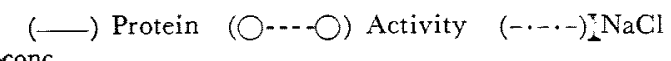

as indicated with an arrow, was precipitated with $90 \%$ saturation of ammonium sulfate. After the precipitate was dissolved in a small amount of water, the solution was dialyzed against $0.01 \mathrm{~m}$ sodium phosphate buffer $(\mathrm{pH}$ 7.0).

This dialyzed fraction showed proteolytic activity on casein from $\mathrm{pH} 5.2$ to $\mathrm{pH} 6.0$, and also exhibited strong esterolytic activity on ATEE at $\mathrm{pH}$ 8.0. The proteolytic activity was partially inhibited by both $10^{-3} \mathrm{M}$ PCMB and $10^{-3} \mathrm{M}$ DFP, while esterolytic activity was completely inhibited with these reagents. These facts suggest that this fraction still contained at least two proteinases. So, further fractionation was conducted.

e) Chromatography on DEAE-Sephadex A-50. The dialyzed solution $(9 \mathrm{ml}, 14.3 \mathrm{mg}$ of protein per $\mathrm{ml}$ ) was applied on DEAE-Sephadex A-50 column $(0.8 \times 32 \mathrm{~cm})$ equilibrated with the same buffer as the dialyzing solution, and developed by increasing linearly the concentration of sodium chloride from $0.1 \mathrm{~m}$ to $0.45 \mathrm{M}$ in $0.01 \mathrm{M}$ phosphate buffer $(\mathrm{pH} 7.0)$.

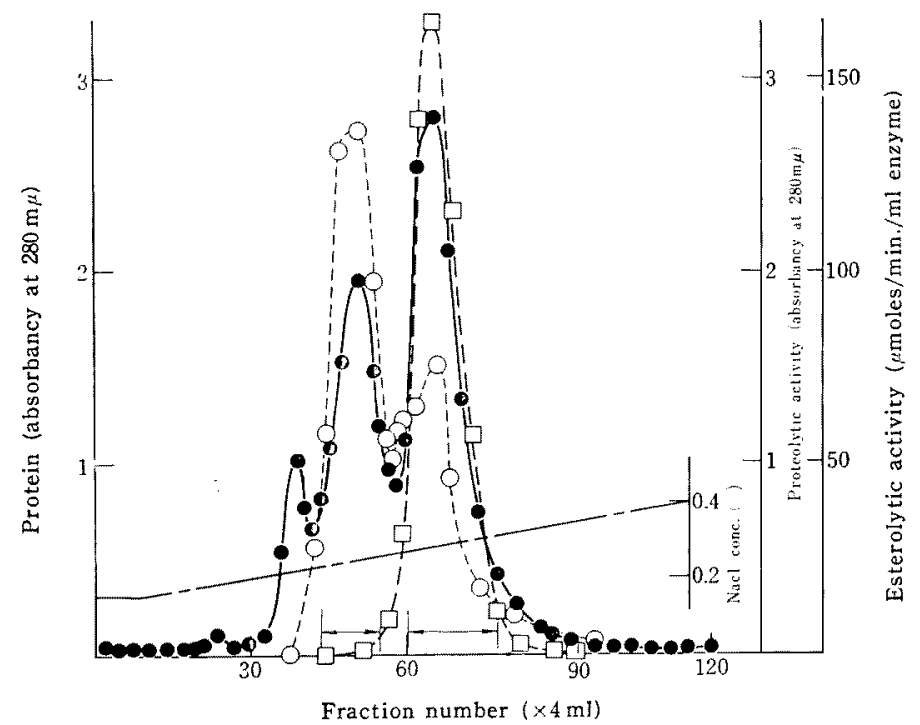

FIG. 4. The Third Chromatography on DEAE-Sephadex A-50 Column $(0.8 \times 32 \mathrm{~cm})$

(- - P Protein, (O--- O) Proteolytic activity, ( $\square---\square)$ Esterolytic activity (--.) $\mathrm{NaCl}$ conc. 
An elution pattern is shown in Fig. 4. At least three peaks of protein were obtained, the last two showing proteolytic activity on casein, and only the last one showed esterolytic activity on ATEE. We designated proteinase $A$ for the enzyme without esterolytic activity and proteinase $\mathrm{C}$ for the enzyme with esterolytic activity.

After the two fractions were pooled as indicated with an arrow in Fig. 4, respectively, some characteristics of each enzyme were tested.

\section{2, Characteristics of proteinase $A$ and $B$}

Enzymatic characteristics of proteinase A were studied with the fraction obtained by DEAE-Sephadex chromatography (see Fig. 4). This fraction exhibited a typical absorption spectrum of protein in the ultra-violet region. Absorbing maximum was at $276 \mathrm{~m} \mu$ and ratio of absorbancy at $280 \mathrm{~m} \mu$ to $260 \mathrm{~m} \mu$ was 1.41 . On the other hand, characteristics of proteinase $B$ were investigated with the "breakthrough" fraction of the first chromatography on TEAE-cellulose (see Fig. 2). Because of the unstable nature of $B$, the above fraction was prepared in the day of the experiment.

a) Effect of $\mathrm{pH}$ on activity. The $\mathrm{pH}$ activity curves of $\mathrm{A}$ and $\mathrm{B}$ for hydrolysis of casein or acid-denatured hemoglobin were presented in Fig. 5 and Fig. 6, respectively. A showed an optimal $\mathrm{pH}$ at 2 for the hydrolysis of casein

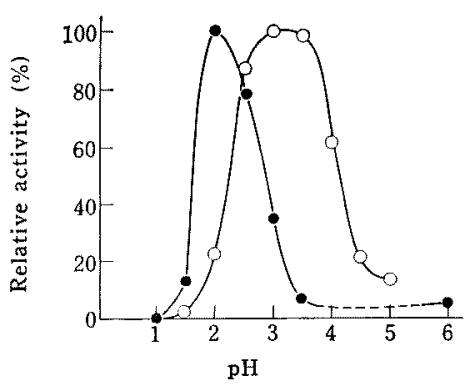

FIG. 5. Activity-pH Gurves of Proteinase A

Enzyme (11.8 $\mu \mathrm{g}$ for casein hydrolysis; $5.9 \mu \mathrm{g}$ acid-denatured hemoglobin hydrolysis) was assayed for $1 \%$ substrate in $0.05 \mathrm{M}$ buffer as follows; glycine buffer, from $\mathrm{pH} 1.0$ to 3.5 ; acetate buffer, from $\mathrm{pH}$ 4.0 to 5.5 , or phosphate buffer, from $\mathrm{pH} 6.0$ to 7.5 .

(-) Hydrolysis of casein

$(\mathrm{O}-\mathrm{O})$ Hydrolysis of $\mathrm{HCl}-\mathrm{Hb}$

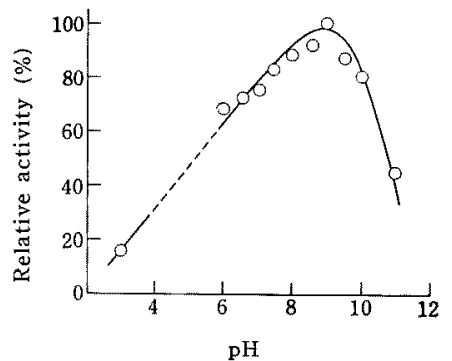

FIG. 6. Activity-pH Curves of Proteinase B.

Enzyme $(540 \mu \mathrm{g})$ was assayed for $1 \%$ casein in $0.05 \mathrm{M}$ borate buffer from $\mathrm{pH} 8.0$ to 11.0 . Other buffers are the same as in Fig. 5.
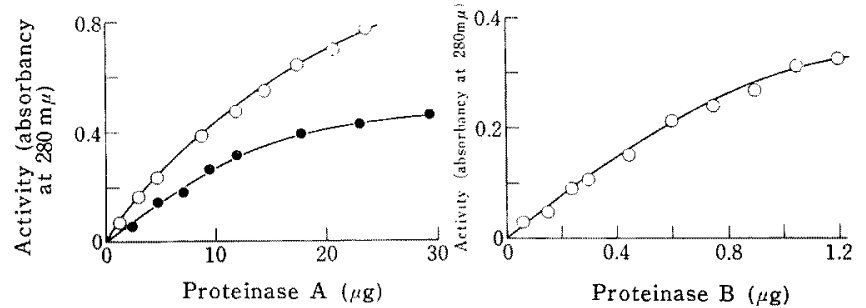

Fig. 7. Effect of Enzyme Concentration of Proteinase A and B on the Hydrolysis of Proteins

Each enzyme was assayed at the optimun $\mathrm{pH}$, using $1 \%$ of casein or acid-denatured hemoglobin as the substrate. The experimental details are described in the text.

(O-O) Hydrolysis of $\mathrm{HCl}-\mathrm{Hb}$

(-) Hydrolysis of casein 
and at 3 for the hydrolysis of acid-denatured hemoglobin. Optimal $\mathrm{pH}$ of $\mathrm{B}$ was at about 9 for the hydrolysis of casein. As shown in Fig. 7 relationships between the activity at optimum $\mathrm{pH}$ of each enzyme and the enzyme concentration showed linearlity until optical density of trichloroacetic acid-soluble products exhibited about 0.3 for both enzymes. Proteinase A showed stronger activity on acid-denatured hemoglobin than on casein.

b) Effect of $\mathrm{pH}$ and temperature on the stability of the enzymes. Stability-pH curves of proteinase $\mathrm{A}$ and $\mathrm{B}$ at various temperature were illustrated in Fig. 8 and Fig. 9, respectively. A was stable from $\mathrm{pH} 5$ to 6 after fifteen hours incubation at $25^{\circ} \mathrm{C}$, and about $90 \%$ of the initial activity remained at $\mathrm{pH} 5$ after thirty minutes incubation at $50^{\circ} \mathrm{C}$. Furthermore, this enzyme was stable under freezing at least for six months. On the other hand, partially purified $\mathrm{B}$ was very unstable enzyme. As shown in Fig. 9 and Fig. 10, only $40 \%$ of initial activity of $B$ remained at the most, after preincubation at $37^{\circ} \mathrm{C}$ for thirty minutes. Although stabilizing effects of many metals $\left(\mathrm{Ca}^{+2}, \mathrm{Mg}^{+2}, \mathrm{Ba}^{+2}, \mathrm{Mn}^{+2}, \mathrm{Fe}^{+2}\right.$ and $\left.\mathrm{Co}^{+2}\right)$, EDTA and L-cysteine, which were known to stabilize

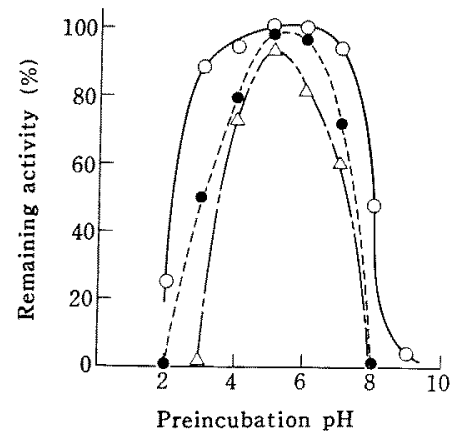

FIG. 8. Stability-pH Curves of Proteinase A.

Proteinase A $(5.8 \mu \mathrm{g})$ was preincubated in $0.4 \mathrm{ml}$ of $0.05 \mathrm{M}$ buffer solution at various conditions, and then remaining activity was assayed as described in the text.

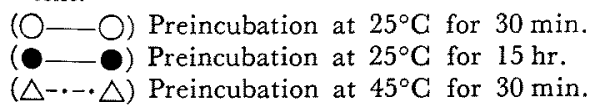

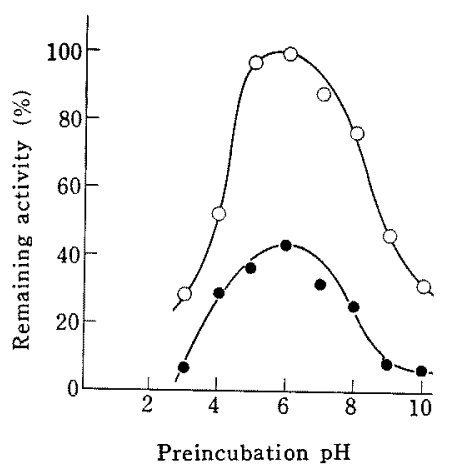

FIG. 9. Stability-pH Curves of Proteinase B

Proteinase B $(580 \mu \mathrm{g})$ was preincubated and assayed at the same conditions as in Fig. 8.

(O- O) Preincubation at $25^{\circ} \mathrm{C}$ for $30 \mathrm{~min}$.

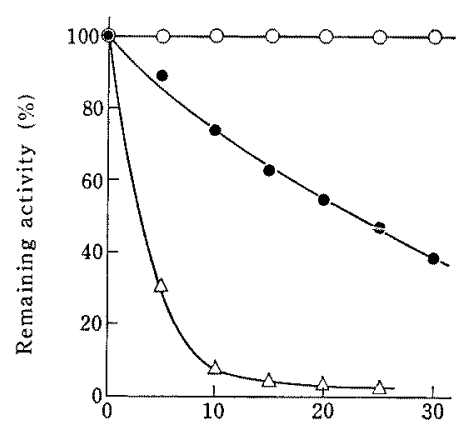

Preincubation time (min.)

FIG. 10. Rate on Inactivation of Proteinase B at Different Temperatures.

Proteinase B $(624 \mu \mathrm{g})$ was incubated in $0.05 \mathrm{M}$ phosphate buffer (pH 6.0), at various temperatures and then remaining activity was assayed as described in the text.

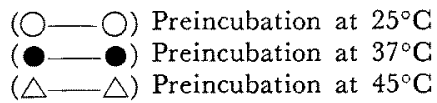

some enzymes, were tested at various concentrations, these materials showed no effect on the stability of $\mathrm{B}$.

c) Effect of various inhibitors and activators on proteinase $\mathbf{A}$ and $B$. After the preincubation of $\mathrm{A}$ or $\mathrm{B}$ with various inhibitors and activators at $\mathrm{pH} 6$ for thirty minutes, remaining activities of these enzymes were determin- 
TABLE I. EFFECT OF VARIOUS INHIBITORS ON ProteINASE A AND B

Inhibitors

Final

Remaining Activity Concentration (M) (1)

$(\%)$

None

DFP

PCMB

Proteinase Proteinase A $B$ $100 \quad 100$ $95 \quad 0$ $10^{-3} \quad 95$ $10^{-4} \quad 100$

(1)

Iodoacetoamide

$10^{-3}$

102

$10^{-4} \quad 101$

$10^{-3} \quad 98$

$10^{-4}$

98
95

$\mathrm{HgCl}_{2}$ $10^{-3}$

97

$0.02 \%$

101

Soy-bean
inhibitor

Proteinase A $(5.9 \mu \mathrm{g})$ or proteinase B $(488 \mu \mathrm{g})$ was preincubated with and without inhibitor in $0.05 \mathrm{M}$ phosphate buffer ( $\mathrm{pH} \mathrm{6.0)}$ ) at room temperature for 30 minutes and then remaining activities were assayed by the method of protein digestion as described in the text.

ed and the results are shown in Table $I$. A was not inhibited by DFP, sulfhydryl reagents and soybean trypsin inhibitor. EDTA and urea (final concentration was $6 \mathrm{M}$ ) did not show any effect on the activity of $A$. On the other hand, $\mathrm{B}$ was strongly inhibited by both
DFP and sulfhydryl blocking reagents. However, L-cysteine $\left(10^{-3} \mathrm{M}\right)$ and 2, 3-dimercaptoethanol $\left(10^{-3} \mathrm{M}\right)$, which are known to activate sulf hydryl enzyme like papain, did not activate this enzyme.

d) Action of proteinase $A$ and $B$ on various synthetic substrates. Hydrolyzing activities of $A$ and $B$ on various synthetic substrates were examined by detecting the products by thinlayer chromatography or titration method. A did not hydrolyze glycylglycine, L-leucylglycine, L-leucylglycylglycine, L-alanylglycylglycine, BAEE, N-acetyl-L-tyrosine amide, and carbobenzoxyglycyl-L-leucine. However, ATEE, carbobenzoxy-L-glutamyl-L-tyrosine, and carbobenzoxyglycyl-L-phenylalanine were slowly hydrolyzed by this enzyme and these hydrolyzing activities were completely inhibited by DFP and PCMB. So, these activities were explained as due to the contamination of proteinase $\mathrm{C}$ as described in the next paper. ${ }^{101}$ As shown in Fig. 11, B showed weakly esterolytic activity on ATEE and BAEE at $\mathrm{pH}$ 8.0. $K_{m}$ values for BAEE and ATEE were $6.5 \mathrm{~mm}$ and $30 \sim 40 \mathrm{~mm}$, respectively, while specific activity on both substrates showed
(A) $K_{m}$ for BAEE and ATEE

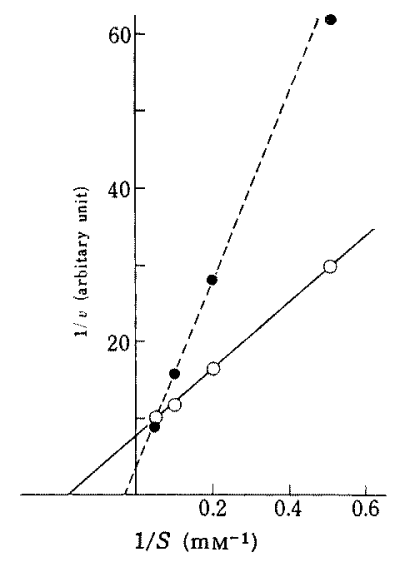

(B) Activity-pH Curves for BAEE and ATEE

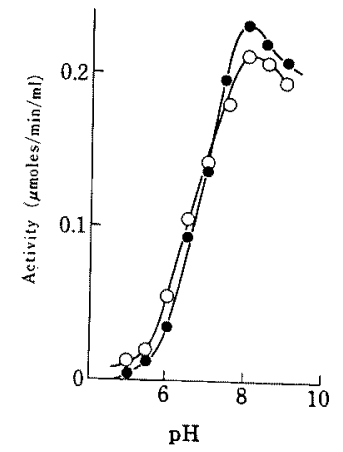

FIG. 11. Effect of $\mathrm{pH}$ and Substrate Concentration for BAEE and ATEE Hydrolysis by Proteinase B

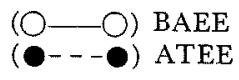


mostly the same value $(0.21 \sim 0.23 \mu$ moles/ minute/ml of enzyme solution). These esterolytic activities of $\mathrm{B}$ were completely inhibited by DFP and PCMB.

e) Milk-clotting activity of proteinase $B$. Milk-clotting activity was the marked characteristics of B which was not found in the cases of A and C. Usually, this activity is determined by measuring the time until particles of casein are formed on the wall of the test tube, using skim milk or dry milk as the substrate. ${ }^{15}$ However, such activity of B was so weak and long time was needed to produce particles of casein. Thus the clotting-activity of $\mathrm{B}$ was determined according to the method as described next, which was based on the fact that this enzyme produces turbidity in casein solution at $\mathrm{pH}$ 6.0. Assay mixture, which contained $0.4 \mathrm{ml}$ of the enzyme solution and $2 \mathrm{ml}$ of $0.6 \%$ casein solution in $0.1 \mathrm{~m}$ sodium acetate buffer $\left(\mathrm{pH} \quad 6.0\right.$ ) containing $10^{-3} \mathrm{M}$ $\mathrm{CaCl}_{2}$, was incubated at room temperature $\left(24 \sim 25^{\circ} \mathrm{C}\right)$, and then optical density at $610 \mathrm{~m} \mu$ was determined with the Hirama photo-electric colorimeter. Activity was expressed as the reciprocal of the time $(1 / T)$ required for 0.5 of optical density at $610 \mathrm{~m} \mu$. Although increase of absorbancy at $610 \mathrm{~m} \mu$ was not proportional
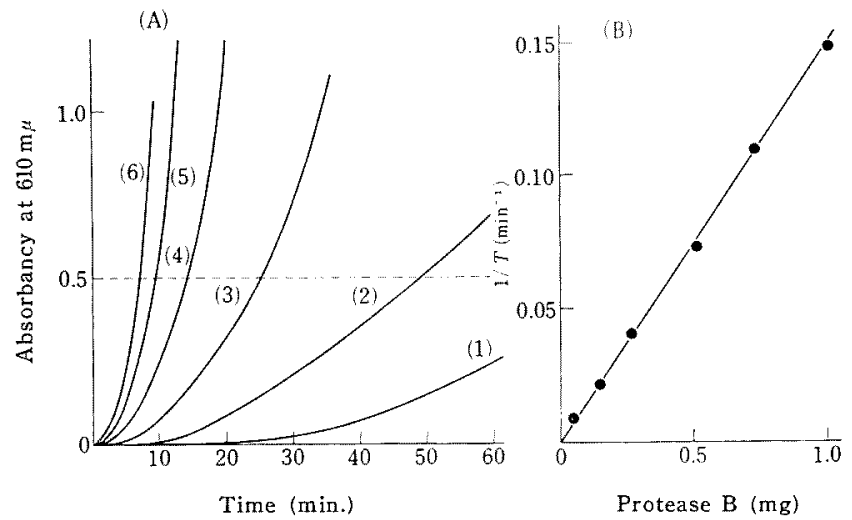

FIG. 12. Casein-clotting Activity of Proteinase B

(A) Time courses of casein-clotting activity of proteinase $B$ determined from optical density difference at $610 \mathrm{~m} \mu$ for various enzyme concentration.

(B) Relationship between enzyme concentration and reciprocal of time $(1 / T)$ when optical density had reached to 0.5 .

Protease B; (1) 0.051 (2) 0.128 (3) 0.255 (4) 0.510 (5) 0.766 (6) $1.020 \mathrm{mg}$.

Table II. Comparison of Varjous activitjes of Proteinase B

\begin{tabular}{|c|c|c|c|c|}
\hline \multirow{3}{*}{ Preincubation } & \multicolumn{4}{|c|}{ Remaining Activity $(\%)$} \\
\hline & & Milk clotting & Esterolytic activity & toward \\
\hline & digestion & activity & $\widehat{\mathrm{BAEE}}$ & ATEE \\
\hline one & 100 & 100 & 100 & 100 \\
\hline $37^{\circ} \mathrm{C}$ for $30 \mathrm{~min}$ & 38 & 32 & 15.4 & 16.9 \\
\hline ith $10^{-4} \mathrm{M}$ PCMB & 0 & 7.2 & 1.5 & 3.1 \\
\hline ith $10^{-3} \mathrm{M}$ DFP & 0 & 2.4 & 2.2 & 0 \\
\hline
\end{tabular}

Experimental conditions are the same as in Table I and Fig. 9.

15) J. R. Whitaker, Food Tech., 13, 86 (1958). 
to the time, $1 / T$ was proportional to the amounts of the enzyme present, as shown in Fig. 12. According to this method, the effect of inhibitors and stability of B were tested and the results are shown in Table II.

f) Comparison of various activities of proteinase B. The stability at $37^{\circ} \mathrm{C}$ and the effect of DFP or PCMB on $\mathrm{B}$ were compared with caseinolytic activity, esterolytic activity and milk-clotting activity. As shown in Table II, the incubation at $37^{\circ} \mathrm{C}$ and the treatment with DFP or PCMB caused almost the same effects toward all of these activities. This fact shows that single enzyme, that is, proteinase $\mathrm{B}$ exhibited those three activities.

\section{Characteristics of Proteinase $\mathrm{C}$}

The fraction of proteinase $\mathrm{C}$, which was obtained from final DEAE-Sephadex chromatography (see Fig. 4), contained $0.89 \mathrm{mg}$ of protein per $\mathrm{ml}$ and nitrogen content of this protein was $13.4 \%$. This fraction showed strong activity on ATEE at pH 8.0 (specific activity was $66.3 \mu \mathrm{g}$ ATEE/minute/mg of protein). Furthermore, this enzyme hydrolyzed carbobenzoxy-L-glutamyl-L-tyrosine and carbobenzoxyglycyl-L-phenylalanine at $\mathrm{pH}$ 5.0. All of these activities were strongly inhibited by both DFP and PCMB as in the case of proteinase B. Detailed characteristics of this enzyme will be reported in the next paper. ${ }^{101}$

\section{DISCUSSION}

According to the earlier studies on yeast proteinases, it was assumed that yeast contained two different proteinases. ${ }^{1,9)}$ One of them was most active at acidic $\mathrm{pH}$ region and the other at slightly acidic or at neutral $\mathrm{pH}$ region, and the latter contained essential sulfhydryl groups like papain. However, their studies had presented confused results concerning to characteristics of each proteinase, because properties of each enzyme had been discussed on yeast autolysate itself without any fractionation or purification.

In the present paper, we fractionated three types of proteinases, designated yeast pro- teinase $A, B$ and $C$, respectively, from the autolysate of baker's yeast by ion-exchange chromatography, and clarified some properties of $\mathrm{A}$ and $\mathrm{B}$.

A had an optimal $\mathrm{pH}$ of 2 for casein and 3 for acid-denatured hemoglobin digestion, and was not inhibited by sulf hydryl brocking reagents like PCMB and mercuric chloride. These properties are fairly resembled to those of "proteinase A" described by Lenney." However, $\mathrm{A}$ in the present study was stable in $6 \mathrm{M}$ urea solution, whereas Lenney's proteinase A was extremely labile in urea solution. On the other hand, enzymatic properties of A were similar to pepsin" and "acidprotease"17) produced by various molds, but $A$ in the present paper could not hydrolyze carbobenzoxy-L-glutamyl-L-tyrosine.

$\mathrm{B}$ was very unstable and its activity was rapidly lost even at $5^{\circ} \mathrm{C}$. Therefore, highly purification could not be carried out, but the comparison of stability at $37^{\circ} \mathrm{C}$ and inhibition by PCMB and DFP proved that proteolytic activity at $\mathrm{pH} 9$, milk-clotting activity at $\mathrm{pH}$ 6 , and esterolytic activity for ATEE and BAEE at $\mathrm{pH} 8$, were shown by a single enzyme, $B$, which was presented in the "breakthrough" fraction of TEAE-cellulose chromatography. B was inhibited not only by PGMB, which generally inhibit sulfhydryl enzyme, but also by DFP, which is specific inhibitor for serine enzyme. This strange characteristics will be discussed in the next paper. ${ }^{10 !}$ Hydrolytic properties of B toward BAEE and susceptibility to sulfhydryl blocking reagents resembled to those of proteinases of plant origin ${ }^{181}$ and cathepsin $\mathrm{B},{ }^{19)}$ but similarity of specific activities toward ATEE and BAEE seems to be unique to yeast proteinase B. Furthermore, milk-clotting activity of proteinase $B$ were

16) F. A. Bovey and S. S. Yanari, "The Enzymes", edited by P. D. Boyer et al., second ed., Academic Press, 1960, Vol. 4, p. 63.

17) B. Hagihara, ibid., p. 193.

18) E. L. Smith and J. R. Kimmel, ibid., p. 133:

19) J. S. Fruton, ibid., p. 233. 
milar to those of papain, ficin and brome- cellulose chromatography, whereas these two in. ${ }^{151}$ enzymes were fractionated on DEAE-Sephadex

Chromatographic behaviors of proteinase A chromatography. The final purification and nd $\mathrm{C}$ were very similar to one another and some physical properties of both enzymes. ould not be separated clearly on TEAE- will be described in the succeeding paper. 